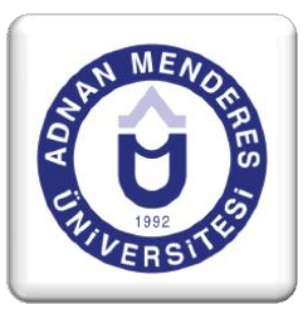

\title{
Konaklama İşletmelerinde Çalışan Yalnızlığının Öznel İyi Oluş Üzerine Etkisi
}

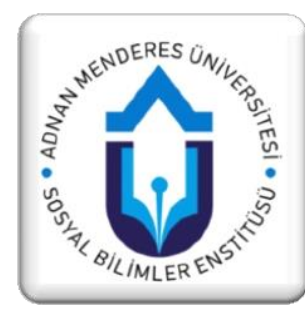

Gülseren YURCU ${ }^{1}$, Özge KOCAKULA ${ }^{2}$

\section{Özet}

Yalnızlık ve öznel iyi oluş kavramları geçmișten günümüze bireylerin yaşamlarında etkili olan iki kavramdır. Yalnızlık ve öznel iyi oluş, bireylerin yaşamlarını olumlu veya olumsuz değerlendirmeleri ile ortaya çıkmaktadır. Bireylerin işyerlerindeki olumlu ve olumsuz duygulanımları performanslarını doğrudan etkilemektedir. $\mathrm{Bu}$ çalışmanın amacı, Konaklama işletmeleri çalışanlarının iş yeri yalnızlık duygularının öznel iyi oluşlarına etkisini ortaya koymaktadır. Bu doğrultuda, Antalya\ Merkez 5 yıldızlı otellerde 406 çalışana anket uygulanmışıır. Araştırmada İş Yaşamında Yalnızlık ve Öznel İyi Oluş ölçekleri kullanılmıştır. Veri analizinde; tanımlayıcı istatistikler, faktör analizi, korelasyon ve regresyon istatistikleri kullanılmıştır. Araştırma sonucunda, yalnızlık ve öznel iyi oluş arasında negatif bir ilişkinin olduğu, yalnızlığın öznel iyi oluşu \%1 etkilediği ortaya çıkmıştır.

Anahtar Kelimeler: Yalnızlık, Öznel İyi Oluş, Konaklama

\section{The Effect of Worker Loneliness İn Workplace on Subjective Well-being in Hospitality}

\begin{abstract}
Loneliness and subjective well-being is two concepts that have the power to effect to human-being. Both of these concept may emerge when people consider themselves as negative or positive but we know that negative or positive self-perception could effect on work performance directly. In this study we aimed to expose the effect of loneliness in workplace feelings on subjective well-being on hospitality workers. With this aim, 406 survey was hold in five stars hotels in Antalya city center. Subjective Well-being Scale and Loneliness in Workplace Scale was used. In order to analize the data, descriptive statistics, factor analyze, regression and correlation analizes was hold. Findings show us loneliness and subjective well-being concepts have negative correlation and loneliness could effect $\% 1$ on the subjective well-being.
\end{abstract}

Key words: Loneliness, Subjective Well-being,Hospitality

\footnotetext{
${ }^{1}$ Adnan Menderes Üniversitesi, Sultanhisar Meslek Yüksekokulu, Öğr.Gör.Dr. gcetin@ adu.edu.tr

${ }^{2}$ Adnan Menderes Üniversitesi, Sultanhisar Meslek Yüksekokulu, Öğr.Gör. $\quad$ ozgekocakula@adu.edu.tr
} 


\section{Giriş}

Yalnızlık duygusu günümüz insanlarının içinde bulundukları yaşam koşulları sonucu ortaya çıkan önemli bir duygu durumudur. Sosyal bir varlık olan insan yaşamı boyunca diğer insanlarla ilişki içerisindedir, ancak, yalnızlık duygusu bireyin tüm dış koşullardan ve insanlardan izole olma durumunu nitelemektedir. Burada kastedilen yalnızlık, insanların fiziksel olarak birbirinden uzak olma halinden öte, bireylerin karş11ıklı sosyal etkileşimden uzak olan zihinsel durumunu ve ruh halini ifade etmektedir (Mercan vd., 2012:215). Dünya Sağlık Örgütü'nün (1946) de tanımlamasıyla artık bireylerin iyilik halleri sadece fiziki durumları ile değil sosyal ve psikolojik durumları ile de değerlendirilmektedir. Bireylerin psikolojik anlamda iyilik hallerini etkileyen önemli değişkenlerden biridir yalnızlık duygusu. Yalnızlık tanımlanması zor bireysel ve toplumsal bir durumdur. Özelliklede günümüz insanının en büyük problemlerinden biridir. Bireyselleşen toplumlar ve karmaşık ilişkiler insanları yalnız hissetmeye sürüklemektedir. Yalnızlık duygusu bireyin çevresine olan güvensizliğini arttırarak uyumunu ve yaşamını zorlaştırmaktadır. Yalnızlık psikolojik birçok hastalığın oluşmasında belirleyici bir rol oynamaktadır (Yaşar, 2007, Jaremka et al., 2013). Yalnız olduğunu düşünen bireyin fiziksel, psikolojik ve sosyolojik iyilik hali olumsuz etkilenmektedir.

Modern toplumlarda yalnızlık duygusu kadar önemli bir diğer kavram ise öznel iyi oluştur. Öznel iyi oluş, yalnızlık duygusu gibi bireylerin kendi yaşamlarına ilişkin öznel değerlendirmeleri ve sosyal etkileşim süreçlerinden aldıkları geri dönütlerle beliren duygulanım durumu olarak ifade edilebilir. Bu duygulanımın ortaya çıkışı, bireyin bilişsel ve duygusal süreçleri tarafından etkilenmektedir. Yalnızlık literatürde, kaygı, öfke, üzüntü, depresyon gibi negatif duygular ile ifade edilmektedir (Yüksel vd., 2013; Yaşar, 2007). Bu duygular bireylerin öznel iyi oluşunu (subjective well-being) olumsuz yönde etkileyen duygu durumlarıdır. Öznel iyi oluş bireylerin yaşamlarındaki pozitif duygulanımlarının toplamını ifade etmektedir.

Günümüz toplumlarında bireylerin sosyal kimliklerini inşa etme, yeniden düzenleme ve var olanı sergileme alanları olarak işyerleri önemli bir yer tutmaktadır. İnsanlar iyi bir çalışma ortamını, iş yerindeki diğer çalışanlara güven duyulan ve onlardan zevk alınan, yapılan işle gurur duyulan yer olarak açıklamaktadır. İş yaşamında çalışanın beklentilerinin karşılanmaması yaşadığı hayal kırıklıkları ve kendi kişiliği yalnızlık yaşamasına neden olabilmektedir. İş yeri yalnızlı̆̆ 1 yalnızlık kavramından farklıdır. İş yeri yalnızlığı duygusal yalnızlıktan daha çok sosyal yalnızlığı (sosyal çevreden kaynaklanan bir başına bırakma, izole etme ve kendi başına olma) ifade etmektedir (Wright, Burt ve Strongman, 2006). Kafetsios (2002) sosyal çevreden kaynaklanan yalnızlığın, sosyal iletişim ağının eksikliğinden ya da ortak ilgi ve etkinliklerin paylaşıldığı bir grubun üyesi olamamaktan kaynaklandığını ve doyum verici bir sosyal ağa ulaşma ile çözüm bulunabilen bir durum olduğunu belirtmiştir. İş yerinde çalışanların yalnızlık duygusu öznel iyi olma hallerini olumsuz etkilemektedir (Erdil ve Ertosun, 2011). İş yerindeki yalnızlık, iş yerindeki insani ilişkilerin kalitesini etkileyebilir (Wright, Burt ve Strongman, 2006).

İlgili literatürde yeterli düzeyde olmasa da işyeri yalnızlığına yönelik çalışmalar bulunmaktadır (Ayazlar, Güzel, 2014; Mercan vd.,2012; Doğan vd., 2009; Erdil ve Ertosun, 2011; Ertosun ve Erdil, 2012). Uzun çalışma süreleri göz önünde bulundurulduğunda, gününün çoğu zaman dilimini işyerinde geçiren turizm çalışanları için yalnızlık duygusu incelenmesi gereken bir durumdur. Ayrıca hissedilen bu yalnızlık duygusunun onların yaşamlarında öznel iyi oluş düzeylerini ne derecede etkilediği de önem arz etmektedir. $\mathrm{Bu}$ noktadan hareketle araştırmanın amacı, konaklama işletmelerinde çalışanların işyeri yalnızlık duygularının öznel iyi oluşlarına etkisini ortaya koymak olarak belirlenmiştir. Bu bağlamda, öncelikle her iki kavramla ilgili yazın kısaca değerlendirilmiş, sonrasında ise araştırma sonuçlarına ilişkin bulgular aktarılmıştır.

\section{Kavramsal Çerçeve}

\subsection{Yalnızlık ve İşyerinde Yalnızlık}

Yalnızlık, bilişsel yaklaşımın öncüsü olarak kabul edilen Peplau ve Perlman'a (1982) göre; bireyin sosyal ilişki ağındaki niceliksel ve niteliksel değerlendirmelerindeki eksiklikler sonucu ortaya çıkan bir 
duygu olarak tanımlanmaktadır. Sullivan (1953) yalnızlığı diğerleriyle yakınlık kurma ihtiyacının yeterince giderilememesi sonucu ortaya çıkan oldukça nahoş, rahatsız edici bir yaşantı olarak kavramlaştırmıştır. Weiss (1973) ise yalnızlığı, kişinin ihtiyaç duyduğu sosyal ilişkilerin olmaması veya değişik sosyal ilişkileri bulunmasına rağmen, bu ilişkilerde yakınlığın, içtenliğin ve duygusallığın bulunmamasına gösterilen bir tepki olarak değerlendirmiştir (Koçak, 2008:14). Tanımlamalardan da yola çıkılarak, yalnızlık duygusu; kişiler arası ilişkilerin sosyal ihtiyaçları karşılamadığı, kişisel ihtiyaçları doyurmayı başaramadığı ve sosyal ödüllerin azaldığı durumlarda ortaya çıkmaktadır (Duru, 2008:16; Eskin, 2001:5). Yalnızlık duygusu bireyin öznel değerlendirmesi sonucu belirlediği ölçütlere göre ortaya çıkmaktadır (Peplau ve Perlman, 1982). Örneğin, çok kalabalık bir ortam bazı bireyleri iyi hissettirirken, bazılarının kendilerini yalnız hissetmesine sebep olabilir.

Weis'e (1973) göre, yalnızlık duygusal ve sosyal olmak üzere iki farklı biçimde yaşanmaktadır (DiTommaso ve Spinner, 1997). Duygusal yalnızlık, diğer insanlar ile yakın ilişki kuramama sonucu ortaya çıkmakta, sosyal yalnızlık ise sosyal ilişkilerden yoksunluk sonucu ortaya çıkmaktadır. Yani ortak bir amacı paylaşan bir arkadaş gurubu içerisinde bulunamamayı ifade etmektedir (Şişman ve Turan, 2004). İnsanların olumlu ilişkiler kurmaları iyi hissetme duygularını arttırmakta, bir arada olmanın getirdiği sosyal destek algısı ile pozitif yönde olumlu duyguların artışı desteklenmektedir (Uzuner ve Karagün, 2014).

İşyeri yalnızlığı, Wright ve diğerleri (2006) tarafından, çalışanın işyerindeki sosyal yalnızlığı olarak ifade edilmektedir. Yani, çalışanın iş ortamında kendini sosyal çevreden uzak, sosyal destek ve yakın ilişkilerden yoksun hissetmesidir. Yapılan çalışmalar işyeri yalnızlığının, örgütsel iklim, iş doyumu, örgütsel bağl1lık, yaşam doyumu, örgütsel aidiyet v.b. örgütsel davranışları olumsuz etkilediğini ortaya koymaktadır (Erdil ve Ertosun, 2011; Ertosun ve Erdil, 2012; Ayazlar ve Güzel, 2014; Mellor et. al., 2008; Y1lmaz ve Aslan, 2013; Şişman ve Turan, 2004).

\section{2. Öznel İyi Oluş}

Öznel iyi oluş Bradburn (1969) tarafından bireyin yaşantıları sonucu meydana gelen olumlu ya da olumsuz duygularına ilişkin yaptığı değerlendirme olarak tanımlamaktadır (Diener, 1984). Bu duygulanımın birey tarafindan olumlu olarak değerlendirilmesi, Lyubomirsky (2007) tarafından ifade edildiği şekliyle neşe, tatmin ya da refah ile yaşamdan duyulan memnuniyetin bir birleşimi olarak karşımıza çıkmaktadır. Öznel iyi oluş kavramına ilişkin birçok tanım olmakla beraber en geçerli tanımın Diener (1984)'a ait olduğu görülmektedir. Diener (1984)'a göre öznel iyi oluş, "bireyin sahip olduğu olumlu ve olumsuz duygulara ve yaşamdan aldığı doyuma ilişkin olarak yaptığı öznel bir değerlendirmedir". Öznel iyi olma, bireyin yaşamına ilişkin kendi değerlendirmeleri üzerinde yoğunlaştığı için öznel bir bakış açısını yansıtmaktadır. Bu değerlendirme, bireyin çeşitli olaylara verdiği tepkileri, içinde bulunduğu duygu durumunu, yaşamdan aldığ doyuma ilişkin düşüncelerini, iş, arkadaşlık, okul, evlilik gibi çeşitli yaşam alanlarına ilişkin aldığ doyumları içermektedir (Diener vd., 2003).

Öznel iyi oluş, olumlu duygulanım, olumsuz duygulanım ve yaşam doyumu olmak üzere üç boyutlu bir yapı göstermektedir (Deiner, 1984; Andrews ve Whitney, 1976). Olumlu duygulanım, güven, ilgi, ümit, heyecan, gurur, neşe gibi duyguları; olumsuz duygulanım ise öfke, nefret, suçluluk, üzüntü gibi olumsuz duyguları içermektedir. Yaşam doyumu boyutu ise, öznel iyi oluşun bilişsel bileşenidir. Bireyin çeşitli yaşam alanlarındaki doyumuna ilişkin değerlendirmelerini yansıtmaktadır. Kişi haz veren yaşantıları daha çok deneyimliyor ve haz vermeyen yaşantıları daha az deneyimliyorsa bu durumda yüksek öznel iyi oluşa sahiptir. Sonuç olarak; öznel iyi oluş, bireyin kendi yaşamını bilişsel ve duygusal açıdan öznel olarak değerlendirmesini içermektedir (Myers ve Deiner:1995).

Erdil ve Ertosun (2011) çalışmalarında; çalışanlar arasındaki pozitif ilişkilerin desteklendiğinde yalnızlığın azaldığını ve iyilik durumlarının önemli ölçüde etkilendiğini ortaya koymuşlardır. Örgütlerde ve 
Adnan Menderes University, Journal of Institute of Social Sciences, Year:2 Volume: 1 (pp. 30-41)

çalışanlarda pozitif iş yaşamı deneyimlerinin arttırılarak pozitif çıktıların kazanılabileceğini belirtmektedirler.

\section{3. İşyeri Yalnızlığı ve Öznel İyi Oluş İlişkisi}

Bireylerin yalnızlık duygusu öznel iyi oluşları gibi kişilik özellikleri, kendine güven, sosyal ilişkiler, demografik faktörler (cinsiyet, medeni durum, gelir, yaş v.b.) ile ilişkilidir (Peplau ve Perlman,1981:43, Cheng ve Furnham, 2002). Bu değişkenlere göre birey yaşantısını olumlu veya olumsuz olarak değerlendirmektedir. Bireylerin yaşantılarını olumlu değerlendirmeleri öznel iyi oluş düzeylerini yükseltmekte iken, olumsuz değerlendirmeleri bu düzeyi düşürmektedir. Özellikle turizm işletmelerinde rekabet ortamının getirdiği zor çalışma koşulları, çalışanın yaşamındaki radikal değişimler sonucu ortaya çıkan olumsuz durumlar çalışan öznel iyi oluş düzeyinin düşmesine neden olmaktadır. Bu sebeplerden biride yalnızlık duygusudur. Yalnızlık duygusu bireylerin yaşantılarını değerlendirmelerinin olumsuz olmasına sebep olmaktadır (Bozorgpour ve Salimi, 2012). Yani, yalnızlık duygusu öznel iyi oluşu negatif etkilemektedir (Bramston et.al., 2002; Y1lmaz ve Aslan, 2013).

Mellor ve diğerleri (2008) çalışmalarında yalnızlığın ait olma duygusuyla zayıf ilişkili olduğu, yaşam doyumu ile güçlü bir ilişkiye sahip olduğu sonucuna ulaşmışlardır. Yılmaz ve Aslan'ın (2013) öğretmenler üzerine yaptıkları çalışmalarında, öğretmelerin yaşam doyumları ile iş yerindeki yalnızlık duyguları (duygusal yoksunluk ve sosyal arkadaşlık) arasında negatif yönlü anlamlı bir ilişki olduğunu bulmuşlardır.

Çalışan günlük zaman diliminin çoğunu işyerinde geçirmektedir. Çalışanın yalnızlık hissetmesi gerek işyerinde gerekse işyeri dışı yaşamında olumsuz etkilenmesine neden olmaktadır. Ayazlar ve Güzel'in (2014) Didim'de bulunan beş yıldızlı otel çalışanları üzerine yaptıkları çalışmalarında, yalnızlığın örgütsel bağlılı̆̆ negatif etkilediğini belirtmişlerdir. Lam ve Lau (2012) işyeri yalnızlığının işyeri ilişkilerinde önemli bir fenomen olduğunu ve çalışan davranışlarını etkilediğini belirtmektedir.

İlgili literatür incelemesinde öznel iyi oluş ve iş yeri yalnızlığına yönelik araştırmalar mevcuttur (Diener, 1984; Diener, 2009; Şişman ve Turan, 2004; Diener, vd. 2003; Malkoç, 2011; Peplau ve Perlman, 1982; Rehdanz ve Maddison, 2003; Oktan, 2012; Doğan ve Eryılmaz, 2013; Uzuner ve Karagün, 2014 vb.). $\mathrm{Bu}$ çalışmalarda işyeri yalnızlık ve öznel iyi oluş kavramlarının sosyal destek, yaşam doyumu, yaşam dengesi (Chalise et. all., 2006), örgütsel iklim (Erdil ve Ertosun, 2011), örgütsel aidiyet (Ertosun ve Erdil, 2012), örgütsel bağl1lık (Ayazlar ve Güzel, 2014), yaşam doyumu ve ait olma ihtiyac1 (Mellor et. all., 2008), duygusal zeka ve psikolojik sermaye (Mercan ve diğerleri, 2013), yaşam doyumu (Yılmaz ve Aslan, 2013), iş doyumu (Şişman ve Turan, 2004) v.b. kavramlarla ilişkisi incelenmiştir. İş yerindeki yalnızlık ve öznel iyi oluş kavramlarının ilişkisinin incelendiği çalışmaların yeterli düzeyde olmadığı dikkat çekmektedir, bu nedenle kavramlarla ilgili daha çok araştırma yapılması gerektiği düşünülmektedir. Özellikle de çalışan psikolojisinin önemli olduğu turizm işletmelerinde bu kavramların incelenmesi gerekmektedir. Bu kapsamda turizm çalışanlarının hissedilen iş yeri yalnızlık duygularının farklı boyutlarda araştırılması ve öznel iyi oluş düzeylerinin arttırılmasının önemli olduğu düşünülmektedir.

\section{Materyal ve Yöntem}

Araştırmanın çalışma alanı, Antalya İl Kültür ve Turizm Müdürlüğü verilerine göre, Antalya İli merkezindeki 5 yıldızlı otellerde çalışanlar olarak belirlenmiştir. Araştırma için kesin personel sayısına ulaşılamamasından dolayı anket uygulama sürecinde insan kaynakları departmanları tarafindan belirtilen toplamda 5459 çalışan araştırmanın evrenini oluşturmaktadır. Araştırmada örneklem seçiminde tesadüfi örnekleme yöntemlerinden basit rassal örneklem yöntemi belirlenmiştir. Anket uygulama sürecinde 5459 otel çalışanından 406 çalışana ulaşılmıştır. Araştırmada kullanılan veri toplama tekniği ankettir. Araştırma verilerini toplamak amacıyla oluşturulan soru formu 3 bölümden oluşmaktadır. Birinci bölümde demografik değişkenler (Yaş, cinsiyet, eğitim durumu, medeni durum, meslek sevgisi, kadro durumu, turizm sektöründe geçirilen süre, aynı işyerinde geçirilen süre, gelir durumu), ikinci bölümde İş Yaşamında Yalnızlık Ölçeği (IYYÖ), üçüncü bölümde Öznel İyi Oluş Ölçeği yer almaktadır. Çalışanların iş yaşamlarında yaşadıkları 
yalnızlığı ölçmek amacıyla Wright, Burt ve Strongman (2006) tarafından geliştirilen, Türkçe uyarlamasını Doğan ve diğerlerinin (2009) çalışmalarında kullandıkları 16 ifadeli ölçek kullanılmışıı. Çalışanların genel öznel iyi oluş düzeylerini ortaya koymak için ise yaygın olarak kullanılan Oxford Happiness Inventory'ın (OHI, Argyle et al., 1989) Hills ve Argyle'nin (2002) çalışmalarında kullandıkları 29 ifadeli orjinal ölçek kullanılmıştır. Katılımcıların ankette yer alan ifadelere: 5'li likert tipinde, (1) Kesinlikle katılmıyorum (2) Katılmıyorum (3) Kararsızım (4) Genellikle katılıyorum (5)Kesinlikle katıliyorum seçenek aralıklarında cevap vermeleri istenmiştir. Araştırma için gerekli veriler 2013 yılı yüksek sezon olarak adlandırılan Haziran-Ağustos aylarında toplanmıştır. Soru formu ile toplanan veriler SPSS 18 istatistiksel veri analizi paket programı ile analiz edilmiş ve yorumlanmıştır. Demografik değişkenlere ilişkin veriler, frekans ve yüzde değerleri kullanılarak değerlendirilmiştir. Araştırmada kullanılan İş Yaşamında Yalnızlık Ölçeği (IYYYÖ) ve Öznel İyi Oluş ölçeklerinin güvenilirliklerini ölçmek için Cronbach Alpha güvenilirlik analizi kullanılmıştır. Çok değişkenli analizlerde verilerin normal dağılıp dağılmadığını belirlemek için Kolmogorov-Simirnov testi yapılmış ve yapılan bu test sonucu verilerin normal dağılıma sahip olmadığı görülmüştür. İş yaşamında yalnızlık ölçeğinin yap1 geçerliliğinin sınanabilmesi için faktör analizi uygulanmıştır. İş yaşamında yalnızlık ve Öznel İyi Oluş değişkenlerinin ilişkisini belirlemek için Spearman korelasyon analizi, değişkenlerin birbirleri üzerindeki etkilerini belirlemek amacıyla doğrusal regresyon analizinden yararlanılmıştır.

Araştırmanın hipotezleri;

$\mathrm{H}_{1}$ : İş yaşamında yalnızlık boyutları ve öznel iyi oluş arasında negatif bir ilişki vardır.

$H_{l a}$ : İs yaşamında yalnızlı̆̆ın boyutlarından duygusal yoksunluk ile öznel iyi oluş arasında negatif ilişki vardir.

$H_{2 b}$ : $\dot{I}_{S}$ yaşamında yalnızlı̆̆ın boyutlarından sosyal arkadaşlık öznel iyi oluş arasında negatif ilişki vardır.

$\mathrm{H}_{2}$ : İş yaşamında yalnızlık boyutları öznel iyi oluşu negatif etkilemektedir.

$\mathrm{H}_{2 a}$ : Iss yaşaminda yalnızlığın boyutlarından duygusal yoksunluk öznel iyi oluşu negatif etkilemektedir.

$H_{2 b}$ : İs yaşamında yalnızlı̆̆ın boyutlarından sosyal arkadaşlı öznel iyi oluşu negatif etkilemektedir.

olarak belirlenmiştir. Bu hipotezler doğrultusunda araştırma modeli Şekil 1'deki gibi kurulmuştur.

Araştırma modeli Şekil 1'de gösterilmektedir.

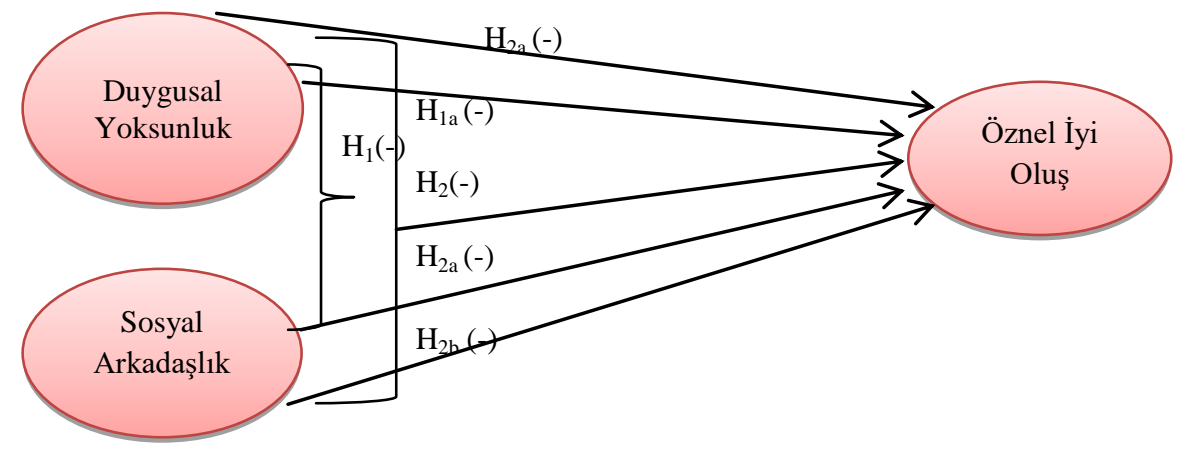

Şekil 1:Araştırma Modeli 


\section{Araştırma Bulguları}

Bu bölümde araştırmanın veri analizi sonucu elde edilen bilgiler yer almaktadır.

\subsection{Geçerlilik ve Güvenilirlik Bulguları}

Kullanılan ölçeğin güvenilirlik analizinde Alfa $(\alpha)$ modeli (Cronbach Alpha Coefficient) kullanılmıştır. Araştırmada kullanılan ölçeğin genel geçerlilik ve güvenilirlik analizinde Cronbach Alpha katsayısı 0,85, İş Yaşamında Yalnızlık ölçeğinin Cronbach Alpha katsayısı 0,82, Öznel İyi Oluş ölçeğinin Cronbach Alpha katsayısı $0,88^{\prime}$ dir. $\mathrm{Bu}$ araştırma ölçeğinin yüksek seviyede güvenilir olduğunu göstermektedir.

\section{2. İş Yaşamında Yalnızlık Faktör Analizi ve Ölçek Geçerliliği}

İş Yaşamında Yalnızlık ölçeği yapı geçerliliğinin sınanabilmesi için faktör analizi uygulanmıştır. Örneklem büyüklüğünün yeterliliğini test etmek için Kaiser-Meyer-Olkin (KMO) ve değişkenlerin normal dağılıma sahip olup olmadığını belirleyebilmek için Barlett Sphericity testi yapılmıştır. İş Yaşamında Yalnızlık ölçeğinin KMO değeri 0,859, Barlett Sphericity testi sonuçları da anlamlıdır. Faktör analizi ve varimax döndürme işlemi yapıldıktan sonra İş Yaşamında Yalnızlık ölçeğinin öz değeri (eigenvalue) birden büyük iki boyut belirlenmiş ve iki boyut toplam varyansın \%63,113'ünü açıklamaktadır. Aşağıdaki tabloda İş Yaşamında Yalnızlığın hangi faktörler altında toplandığı gösterilmektedir.

Tablo:1 İş Yaşamında Yalnızlık Ölçeği Faktör Analizi

\begin{tabular}{|c|c|c|c|c|}
\hline 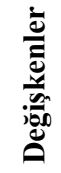 & İfadeler & $\begin{array}{l}\text { Faktör } \\
\text { Yükleri }\end{array}$ & $\begin{array}{l}\text { Faktör } \\
\text { Geçerlilikleri }\end{array}$ & $\begin{array}{l}\text { Faktör } \\
\text { Varyansı }\end{array}$ \\
\hline \multirow{8}{*}{ 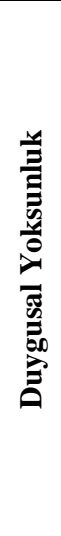 } & $\begin{array}{l}\text { 1. İş ortamında baskı altındayken iş arkadaşlarım tarafından yalnız } \\
\text { bırakıldığımı hissederim }\end{array}$ & ,781 & \multirow{8}{*}{, 88} & \multirow{8}{*}{27,800} \\
\hline & $\begin{array}{l}\text { 2. Çoğunlukla iş arkadaşlarımın } \text { bana mesafeli durduklarını } \\
\text { hissediyorum. }\end{array}$ & ,866 & & \\
\hline & $\begin{array}{l}\begin{array}{l}\text { 3. Birlikte çalıştığım insanlarla arama mesafe } \\
\text { hissediyorum. }\end{array}\end{array}$ & 805 & & \\
\hline & 4. Kendimi iș arkadaşlarımdan duygusal olarak uzak hissediyorum. & ,692 & & \\
\hline & $\begin{array}{l}\text { 7. İş arkadaşlarımla birlikteyken çoğu zaman kendimi dışlanmış } \\
\text { hissediyorum. }\end{array}$ & ,712 & & \\
\hline & $\begin{array}{l}\text { 8. İş yerinde çoğu zaman diğer çalışanlarla birlikte aramda bir kopukluk } \\
\text { hissederim. }\end{array}$ &, 811 & & \\
\hline & 9. İş yerindeyken kendimi genel bir boşluk duygusu içinde hissederim. & ,700 & & \\
\hline & $\begin{array}{l}\text { 13. İş yerinde istediğimde kişisel düşüncelerimi paylaşabileceğim } \\
\text { kimse yoktur. }\end{array}$ &, 548 & & \\
\hline \multirow{8}{*}{ 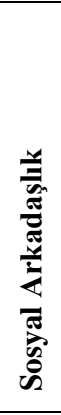 } & 5. İş yerimdeki ilişkilerimden memnunum. & ,681 & \multirow{8}{*}{,88 } & \multirow{8}{*}{35,313} \\
\hline & 6. Çalıștığım iș yerinde dostluk anlayıșı hakimdir. & 666 & & \\
\hline & 10. İş yerinde sosyal ilişkilerim vardır. & ,750 & & \\
\hline & 11. İş yerimdeki sosyal etkinliklere (piknik, parti, yemek vs.) katılırım. & ,751 & & \\
\hline & $\begin{array}{l}\begin{array}{l}\text { 12. İş yerinde gerektiğinde } \\
\text { konuşabileceğim biri var. }\end{array} \\
\end{array}$ & ,633 & & \\
\hline & $\begin{array}{l}\text { 14. İş yerinde mola zamanlarında beraber vakit geçirebileceğim biri } \\
\text { vardır. }\end{array}$ &, 811 & & \\
\hline & $\begin{array}{l}\text { 15. Kendimi iş yerindeki arkadaş grubunun bir parçası olarak } \\
\text { hissederim. }\end{array}$ & ,829 & & \\
\hline & 16. İş yerinde beni dinleme zahmetinde bulunan insanlar vardır. & ,788 & & \\
\hline \multicolumn{3}{|c|}{$\begin{array}{l}\text { KMO:0,85 } \\
\text { P:,000 (Barlett's Test) } \\
\end{array}$} & \multicolumn{2}{|c|}{ Toplam Varyans:63,113 } \\
\hline
\end{tabular}


Faktörlere ilişkin Cronbach Alpha değerlerinin pozitif ve \%60'ın üstünde olması, ölçeğin oldukça güvenilir olduğunu göstermektedir. Bu değerler duygusal yoksunluk faktöründe ,88; sosyal arkadaşl1k faktöründe ,88 olarak tespit edilmiştir. Doğan ve diğerlerinin (2009) çalışmalarında, ilk 9 madde "Duygusal Yoksunluk" alt boyutunu, son 7 madde ise "Sosyal Arkadaşlık" alt boyutunu oluşturmaktadır. Bu araştırmada ise, ifadeler Tablo-1'de görüldüğü gibi "Duygusal yoksunluk boyutunda $(1,2,3,4,7,8,9,13)$ ve Sosyal arkadaşlık boyutunda $(5,6,10,11,12,14,15,16)$ " dağılmıştır.

\subsection{Demografik Değișkenlere İlişkin Bulgular}

Araştırmaya katılan çalışanların demografik değişkenlerine ilişkin veriler Tablo-2'de gösterilmektedir.

Tablo 2: Araştırmaya Katılanların Demografik Değişkenlerine İlişkin Bulgular

\begin{tabular}{|c|c|c|c|c|c|c|c|}
\hline \multicolumn{2}{|c|}{ Değişkenler } & \multirow{2}{*}{$\begin{array}{c}\begin{array}{c}\text { Frekans } \\
\text { f }\end{array} \\
9\end{array}$} & \multirow{2}{*}{$\begin{array}{c}\begin{array}{c}\text { Yüzde } \\
\%\end{array} \\
2,2 \\
\end{array}$} & \multicolumn{2}{|c|}{ Değişkenler } & \multirow{2}{*}{$\begin{array}{c}\begin{array}{c}\text { Frekans } \\
\mathbf{f}\end{array} \\
157\end{array}$} & \multirow{2}{*}{$\begin{array}{c}\begin{array}{c}\text { Yüzde } \\
\%\end{array} \\
38,8 \\
\end{array}$} \\
\hline \multirow{5}{*}{ Yaş } & 18 yaş altı & & & \multirow{6}{*}{$\begin{array}{c}\text { Meslek } \\
\text { Y1lı }\end{array}$} & $1-5$ & & \\
\hline & $18-26$ & 118 & 29,3 & & $6-10$ & 137 & 33,8 \\
\hline & $27-35$ & 165 & 40,9 & & $11-15$ & 78 & 19,3 \\
\hline & $36-44$ & 78 & 19,4 & & $16-20$ & 27 & 6,7 \\
\hline & $\begin{array}{l}45 \text { yaş ve } \\
\text { üzeri }\end{array}$ & 33 & 8,2 & & $21-25$ & 4 & 1,0 \\
\hline \multirow{2}{*}{ Cinsiyet } & Erkek & 209 & 55,7 & & 26-üzeri & 2 &, 5 \\
\hline & Kadın & 166 & 44,3 & \multirow{6}{*}{$\begin{array}{c}\text { Aynı } \\
\text { İşyerinde } \\
\text { Çalış1lan } \\
\text { Süre }\end{array}$} & $1-5$ & 272 & 72,5 \\
\hline \multirow{6}{*}{$\begin{array}{l}\text { Eğitim } \\
\text { Durumu }\end{array}$} & İlköğretim & 70 & 17,3 & & 6-10 & 72 & 19,2 \\
\hline & Lise & 204 & 50,5 & & $11-15$ & 24 & 6,4 \\
\hline & Önlisans & 71 & 17,6 & & $16-20$ & 4 & 1,1 \\
\hline & Lisans & 49 & 12,1 & & $21-25$ & 1 &, 3 \\
\hline & $\begin{array}{l}\text { Yüksek } \\
\text { Lisans }\end{array}$ & 10 & 2,5 & & 26-üzeri & 2 &, 5 \\
\hline & Doktora & - & - & \multirow{5}{*}{$\begin{array}{c}\text { Gelir } \\
\text { Durumu }\end{array}$} & 500 ve alt 1 & 12 & 3,1 \\
\hline \multirow{2}{*}{$\begin{array}{l}\text { Medeni } \\
\text { Durum }\end{array}$} & Evli & 198 & 49,6 & & $500-1000$ & 151 & 39,3 \\
\hline & Bekar & 201 & 50,4 & & $1001-1500$ & 161 & 41,9 \\
\hline \multirow{2}{*}{$\begin{array}{l}\text { Kadro } \\
\text { Durumu }\end{array}$} & Daimi & 255 & 64,6 & & $1501-2000$ & 30 & 7,8 \\
\hline & Geçici & 140 & 35,4 & & $\begin{array}{ll}2001 & \text { ve } \\
\text { üzeri } & \end{array}$ & 30 & 7,8 \\
\hline
\end{tabular}

Tablo 2 incelendiğinde, araştırmaya katılanların \%40,9'unun 27-35, \%29,3'ünün 18-26, \%19,4'ünün 36-44, \%8,2'inin 45 yaş ve üzeri, \%2,2'inin 18 yaş ve altı yaş gurubundadır. Katılımcıların ağırlıklı olarak 18-35 yaş gurubunda olduğu görülmektedir. Araştırmaya katılan çalışanların \%55,7'ini erkekler, \%44,3'ünü kadınlar oluşturmaktadır. Çalışanların eğitim durumları incelendiğinde önemli bir bölümünün $(\% 50,5)$ lise mezunu olduğu görülmektedir. \%50,4'ü bekar, \%49,6'1 evlidir. Çalışanların \%64,6'1 daimi, \%35,4'ü de geçici olarak çalışmaktadırlar. Tabloya bakıldığında çalışanların bu meslekteki çalışma yılları itibariyle $\% 38,8$ 'nin 1-5, \%33,8'nin 6-10, \%19,3'ü 11-15, \%6,7'i 16-20, \%1,0'ı 21-25 ve \%0,5'inin 26-üzeri çalışma yılına sahip olduğu görülmektedir. Katılımcıların büyük bir çoğunluğunun bu mesleğe yeni girdiği gözlenmektedir. $\mathrm{Bu}$ veriler doğrultusunda aynı işyerinde çalışma yılları itibariyle \%72,5'inin 1-5 yıl aralığında çalışmaktadırlar. Turizm sektörünün iş devir hızının yüksekliği ve tecrübe düzeyleri bu tablolarda gözlenmektedir. Araştırmaya katılanların \%41,9’u 1001-1500 TL, \%39,3’ü 500-1000 TL, \%7,8'i 1501-2000 
TL, \%7,8'i 2001 ve üzeri TL, \%31'i 500 ve altı TL gelirleri bulunmaktadır. Ortalama bir ailenin geçim şartları gözönüne alındığında elde edilen gelirlerin yeterli düzeyde olmadığı görülmektedir.

\subsection{Araştırma Hipotezlerine İlişkin Bulgular}

\subsection{1. İş Yaşamında Yalnızlık Boyutları ve Öznel İyi Oluş İlişkisi}

Tablo 3'de araştırmaya katılan çalışanların iş yaşamındaki yalnızlıkları ile öznel iyi oluşları arasındaki ilişki gösterilmektedir.

Tablo 3: İş Yaşamında Yalnızlık Boyutları ve Öznel İyi Oluş İlişkisi

\begin{tabular}{|c|c|c|c|c|c|c|}
\hline & Z & 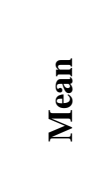 & $\dot{\omega}$ & & 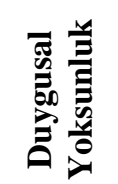 & 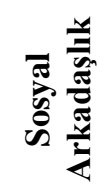 \\
\hline $\begin{array}{l}\text { Öznel } \\
\text { Oluş }\end{array}$ & 403 & 3,5739 & ,658 & \multirow{4}{*}{,- 024} & $\begin{array}{l}-, 076 \\
, 150\end{array}$ & $\begin{array}{l}067 \\
, 205\end{array}$ \\
\hline $\begin{array}{l}\text { Duygusal } \\
\text { Yoksunluk }\end{array}$ & 406 & 2,2262 & 1,114 & & 1 & \\
\hline $\begin{array}{l}\text { Sosyal } \\
\text { Arkadaşlık }\end{array}$ & 406 & 3,8467 & 1,027 & & $\begin{array}{c}-, 090 \\
, 086\end{array}$ & 1 \\
\hline $\begin{array}{l}\text { İs } \\
\text { Yaşamında } \\
\text { Yalnızlık }\end{array}$ & 406 & 3,0351 &, 752 & & $\begin{array}{c}, 641 * * \\
, 000\end{array}$ & $\begin{array}{c}, 580 * * \\
, 000\end{array}$ \\
\hline
\end{tabular}

**. Correlation is significant at the 0.01 level (2-tailed).

Tablo-3'de ortalama değerler duygusal yoksunluğun $(X=2,22)$, sosyal arkadaşlığın $(X=3,84)$, iş yaşamında yalnızlığın $(X=3,03)$ ve öznel iyi oluşun $(X=3,57)$ olarak bulunmuştur. Ortalama değerler duygusal yoksunluk davranışının sosyal arkadaşlığa göre daha düşük olduğunu göstermektedir. İş yaşamında yalnızlık boyutları ve öznel iyi oluş arasındaki ilişkiler Spearman korelasyon katsayısı tekniği ile incelenmiştir. İş yaşamında yalnızlık boyutları ve öznel iyi oluş arasında negatif yönlü bir ilişki vardır $(\mathrm{r}=$ $.024, \mathrm{p}<.01)$. Öznel iyi oluş ve duygusal yoksunluk arasında negatif yönlü bir ilişki vardır. $(\mathrm{r}=-.076, \mathrm{p}<.01)$. Öznel iyi oluş ve sosyal arkadaşlık arasında pozitif yönlü anlamlı bir ilişki vardır $(\mathrm{r}=.067, \mathrm{p}<.01)$. Bu sonuçlara göre, genelde yalnızlık ve öznel iyi oluş arasında negatif yönlü bir ilişki vardır, yani çalışanların kendilerini yalnız hissetmeleri öznel iyi oluş düzeylerinde azalmaya sebep olacaktır. Yalnızlık boyutlarından duygusal yoksunluk öznel iyi oluşu azaltırken, çalışanların sosyal arkadaşlıklarının olması öznel iyi oluş seviyelerini arttıracaktır, denilebilir. Bu doğrultuda; $H_{I}$ "İ̧s yaşamında yalnızlık boyutları ve öznel iyi oluş arasında negatif bir ilişki vardır”, $H_{l a}$ "İs yaşamında yalnızlığın boyutlarından duygusal yoksunluk ile öznel iyi oluş arasında negatif ilişki vardır" hipotezi kabul, $H_{2 b}$ "IŞs yaşamında yalnızlığın boyutlarından sosyal arkadaşlık öznel iyi oluş arasında negatif ilişski vardır” hipotezi ise reddedilmektedir. 


\subsection{2. İş Yaşamında Yalnızlık Boyutlarının Öznel İyi Oluşa Etkisi}

Araştırmaya katılan çalışanların iş yaşamındaki yalnızlıklarının öznel iyi oluşlarına etkisi Tablo 4'de gösterilmektedir.

Tablo 4: İş Yaşamında Yalnızlık Boyutlarının Öznel İyi Oluşa Etkisi

\begin{tabular}{|c|c|c|c|c|c|c|}
\hline \multirow[b]{2}{*}{$\begin{array}{l}\text { Bağımlı } \\
\text { Değişken }\end{array}$} & \multirow[b]{2}{*}{ Bağımsız Değişken } & \multicolumn{2}{|c|}{ Katsayı } & \multirow[b]{2}{*}{$\mathbf{t}$} & \multirow[b]{2}{*}{$\mathbf{F}$} & \multirow[b]{2}{*}{$\mathbf{R}^{2}$} \\
\hline & & $\mathbf{B}$ & $\begin{array}{l}\text { S. } \\
\text { hata }\end{array}$ & & & \\
\hline \multirow{3}{*}{ Öznel İyi Oluş } & Sabit değer & 3,464 & ,144 & 24,102 & \multirow{3}{*}{1,982} & \multirow{3}{*}{0,010} \\
\hline & Duygusal Yoksunluk &,- 036 &, 029 & $-1,220$ & & \\
\hline & Sosyal Arkadaşlık & 049 &, 032 & 1,547 & & \\
\hline
\end{tabular}

Tablodaki 1,982 F değeri, modelimizin bir bütün olarak her düzeyde anlamlı olduğunu göstermektedir (Sig.=,000). Parametrelere ait $\mathrm{t}$ istatistik değerlerinden modele dahil edilen her bir değişkenin ayrı ayrı (\%5 anlamlılık düzeyinde) anlamlı olduğu görülmektedir. $\beta$ değeri $(, 049)$ olan sosyal arkadaşlık göreli olarak önemli bağımsız değişkendir. $\beta$ değeri $(-, 036)$ olan duygusal yoksunluk değişkeni öznel iyi oluşu negatif etkilemektedir. Yani duygusal yoksunluk arttı̆ğında öznel iyi oluş azalacaktır. Öznel İyi Oluşu etkileyen faktörler içerisinde duygusal yoksunluk ve sosyal arkadaşl1k düzeyleri öznel iyi oluş düzeyini 0,010 oranında açıklamaktadır $\left(\mathrm{R}^{2}=0,010\right)$. Bu sonuca göre öznel iyi oluştaki \% 1'lik değişim modele dahil ettiğimiz duygusal yoksunluk ve sosyal arkadaşlık değişkenleri tarafından açıklanmaktadır.

Kısaca modelimizin tahmin sonucu aşağıdaki gibidir;

$\mathrm{y}=3,464+(-) 0.036 \mathrm{x}+0.049 \mathrm{x}$

Öznel İyi Oluş $=3,464+(-)$ 0.036(duygusal yoksunluk) +0.049 (sosyal arkadaşlık)

$\mathrm{Bu}$ durumda, $\boldsymbol{H}_{2}$ "íş̧ yaşamında yalnızlık boyutları öznel iyi oluşu negatif etkilemektedir", ve $H_{2 a}$ "İ̧̧ yaşamında yalnızlığın boyutlarından duygusal yoksunluk öznel iyi oluşu negatif etkilemektedir" hipotezleri kabul edilmektedir. $H_{2 b}$ "İş yaşamında yalnızlığın boyutlarından sosyal arkadaşlık öznel iyi oluşu negatif etkilemektedir", hipotezi ise reddedilmektedir.

\section{Tartışma ve Sonuç}

İş Yaşamında Yalnızlık ve Öznel İyi Oluş ölçekleri kullanılarak Antalya'daki beş yıldızlı otel çalışanları üzerinde yapılan bu araştırmada kurulan hipotezler, genel anlamda yalnızlık ile öznel iyi oluş arasında bir ilişki olduğunu öngörmüştür. Araştırmadan çıkan bulgular, yalnızlık ile öznel iyi oluş kavramları arasında negatif $(-, 024)$ yönlü bir ilişkinin varlığını ortaya koymuştur. Yalnızlık boyutlarından duygusal yoksunluğun öznel iyi oluş ile negatif yönlü, sosyal arkadaşlık boyutunun pozitif yönlü ilişkili olduğu sonucuna ulaşı1mıştır. Çalışanların yalnızlık ortalamalarına bakıldığında duygusal yoksunluk $(X=2,22)$ davranışlarının sosyal arkadaşlık $(X=3,84)$ davranışlarına göre daha düşük olduğu görülmektedir. Ortalama değerler itibariyle çalışanların gerek iş yeri gerekse iş dışında yalnız olduklarını ifade ettikleri söylenebilir. İşyeri yalnızlığının incelendiği bu araştırmaya göre, çalışanların sosyal arkadaşlık boyutunun güçlendirilmesi çalışan öznel iyi oluş derecesinde artışa neden olacaktır. Çalışanların iş ortamı içerisinde ve dışarısındaki sosyal ortamlarının (sosyo-kültürel faaliyetler) güçlendirilmesi sosyal beklentilerini karşılayarak öznel iyi oluşlarını arttırabilir. Diener ve Diener (1995) çalışmalarında yakın ilişkilerin yaşam doyumunu arttırdığını ortaya koymuştur.

Araştırmaya katılanların demografik değişkenlerine ilişkin sonuçlarda, büyük çoğunluğunun $(\% 70,2) 18$ 35 yaş aralığında genç çalışanlar olduğu, önemli bir bölümünün $(\% 50,5)$ lise mezunu olduğu görülmektedir. Tablo-2 işletmelerdeki iş devir hızının yüksekliğini de ortaya koymaktadır. Bu durum işyerinde çalışanların ortak bir amaç etrafında toplanma ve sosyal ilişki düzeyini, dolayısıyla yalnızlık düzeylerini arttırıp öznel iyi 
oluşlarını olumsuz etkileyebilir. Çalışanların turizm işletmelerinden elde ettikleri gelir düzeylerinin ise yaşam standartlarının altında olduğu (500-1500) sonucu elde edilmiştir. Bu gelir durumunun sezonluk olduğu da düşünülürse, çalışan öznel iyi oluşunun olumsuz etkileneceği söylenebilir. Bu araştırmada çalışan yalnızlığına demografik değişkenlerin etkisi incelenmemiş̧ir, farklı çalışmalarda bu durum araştırılabilir.

Turizm çalışanlarının bir duygu-durum niteliğinde içselleştirdikleri iş yerindeki yalnızlık duyguları, yine içe dönük bir öz-değerlendirme niteliğinde ele alınan öznel iyi oluş kavramıyla ters yönlü hareket etmektedir. Çalışanların günlük yaşam sürelerinin çoğunu içine alan çalışma sürelerinde duygusal yoksunluk hissetmeleri, öznel iyi oluş algılarını olumsuz yönde etkilemektedir. Ancak, çalışanların sosyal arkadaşlıklarının iyi olması öznel iyi oluş algılarını olumlu yönde etkilemektedir. Elde edilen bu sonuç Mellor et. al. (2008), Yılmaz ve Aslan'ın (2013) çalışmalarını destekler niteliktedir. Araştırma sonucuna göre, turizm çalışanlarının iş yerindeki yalnızlık algıları, öznel iyi oluş algılarındaki değişkenliğin \%1'ini açıklamaktadır. Öznel iyi oluş düzeyini etkileyen birçok değişkenin varlığı gözönüne alındığında elde edilen sonucun dikkate alınması gerektiği düşünülmektedir. Yurcu'nun (2014) çalışmasında örgütsel vatandaşlık (\%8) ve iş doyumunun (\%25) öznel iyi oluş üzerindeki etkisi ortaya konulmuştur.

Bu çalışmada, günümüz iş ilişkileri için önemi artan kavramlardan olan yalnızlık ve öznel iyi oluş söz konusu istatistiksel yöntemlerle incelenmiştir. Bu kavramların, toplumların yapısından giderek yer kaplaması da göz önünde bulundurulduğunda, daha derinlemesine incelenmesi gerektiği anlaş1lmaktadır. Modern toplumların en önemli problemlerinden biri haline gelen yalnızlık duygusu iş yaşamında istikrarlı bir ortamın yakalanmasında engel oluşturabilir. Turizm işletmelerinin rekabet ortamında iş ilişkilerindeki karmaşıklık ve belirsizlik çalışanların yalnızlık duygularını arttırabilir. Turizm işletmelerindeki gelir düşüklügüü çalışanların iş yaşamı içerisinde ve dışarısında sosyo- kültürel faaliyetlerinin ve hatta temel ihtiyaçlarının yeterli düzeyde karşılanamamasına neden olabilir, bu durum iş rutininden kurtulamayan bireyi yalnızlığa dolayısıyla mutsuzluğa itebilir. Aynı şekilde iş devir hızının yüksekliği de iş ortamında çalışanların ortak bir amaçlarının oluşmamasına, çalışanların sosyal arkadaşlık düzeylerinin zayıflamasına neden olarak yalnızlık duygularının artmasına sebep olabilir. Bu araştırma turizm çalışanlarının yalnızlık ve öznel iyi oluşlarına yönelik öncül bir çalışma olarak nitelenebilir. Bu araştırmada nicel yöntemlerle incelenen bu kavramların nitel yöntemlerle daha derinlemesine incelenmesinin, kavramların derinliklerini anlamamıza olanak tanıyan farklı bakış açıları sunacağı ve bu yönüyle literatüre önemli katkı sağlayacağı düşünülmektedir. Turizm çalışanlarının yalnızlık algılarının farklı değişkenler ile ilişkisi incelenebilir. Diğer turizm işletmeleri çalışanlarının da yalnızlık ve öznel iyi oluş düzeylerinin araştırılması işletme yöneticilerine çalışan psikolojisine yönelik önemli bilgiler sunacaktır. Elde edilen bilgiler 1şı̆̆ında konaklama işletmeleri yöneticileri çalışan yalnızlığının giderilmesine yönelik önlemler alabilir ve çalışan yalnızlığını azaltmak için iş yeri aktiviteleri teşvik edilebilir.

\section{KAYNAKÇA}

AYAZLAR G., GÜZEL B.( 2014 ) "The Effect Of Loneliness In The Workplace On Organizational Commitment". Social and Behavioral Sciences, 131, 319-325.

BRAMSTON P., PRETTY G., CHIPUER H. (2002) “ Unravelling Subjective Quality Of Life: An İnvestigation Of İndividual And Community Determinants”. Social Indicator Research, 59, 261-274.

BOZORGPOUR, F., SALIMİ A. ( 2012 ) "State Self-Esteem, Loneliness and Life Satisfaction". Social and Behavioral Sciences.

CHENG, H., FURNHAM, A. (2002) "Personality, Peer Relations, And Self-Confidence As Predictors Of Happiness And Loneliness". Journal of Adolescence, 25, 327-339.

DIENER, E. (1984) “Subjective Well- Being”. Psychological Bulletin, 95(3),542- 575.

DIENER, E., DIEENER, M. (1995) "Cross-cultural correlates of life satisfaction and self-esteem". Journal of Personality and Social Psychology, 68, 653-663.

DIENER, E. (2009) "Subjective Well-Being, The Science Of Well-Being". Social Indicators Research Series, USA, Springer, 37, 11-58. 
DIENER, E., OISHI, S., LUCAS, R. E. (2003) "Personality, Culture And Subjective Wellbeing: Emotional And Cognitive Evaluations Of Life". Annual Review Pyschology, 54, 403-425.

DOĞAN, T., ERYILMAZ, A.(2013) “ İki boyutlu benlik saygıs1 ve öznel iyi oluş arasındaki ilişkilerin incelenmesi”. Pamukkale Üniversitesi Ĕgitim Fakültesi Dergisi, Say1 33 (Ocak, I), 107-117.

DI'TOMMASO, E., SPINNER B. (1997) "Social And Emotional Loneliness: A Reexamination Of Weiss' Typology Of Loneliness". Personal Individual Different, Vol. 22. No. 3, P:421.

DOĞAN,T., ÇETIN, B., SUNGUR, M.Z. (2009) "İş Yaşamında Yalnızlık Ölçeği Türkçe Formunun Geçerlilik Ve Güvenilirlik Çalışması". Anadolu Psikiyatri Dergisi, 10, 271-277.

DURU, E.(2008) "Yalnızlı̆̆ı Yordamada Sosyal Destek ve Sosyal Bağlılığın Rolü”. Türk Psikoloji Dergisi, Haziran, 23 (61), 15-24.

ERDIL O., ERTOSUN Ö. G. (2011) "The Relationship between Social Climate and Loneliness in the Workplace and Effects on Employee Well-Being”. Procedia Social and Behavioral Sciences 24, 505525.

ERTOSUN Ö. G., ERDIL O. (2012) "The Effects of Loneliness on Employees' Commitment and Intention to Leave". Procedia Social and Behavioral Sciences 41,469-476.

ESKİN, M.(2001) "Ergenlikte Yalnızlık, Başetme Yöntemleri ve Yalnızlığın İntihar Davranışı ile İlişkisi”. Klinik Psikiyatri, 4, 5-11.

HILLS, P., ARGYLE M.(2002) "The Oxford Happiness Questionnaire: A Compact Scale For The Measurement Of Psychological Well-Being". Personality And Individual Differences 33, 1073-1082.

JAREMKA, L. M., FAGUNDES, C. P., GLASER R., BENNETT J. M., MALARKEY W.B., KIECOLTGLASER J. K. (2013) "Loneliness Predicts Pain, Depression, And Fatigue: Understanding The Role Of İmmune Dysregulation". Psychoneuroendocrinology 38,1310-1317.

KAFETSIOS, K. (2002) "Attachment, Social Support And Well-Being Across The Life-Span: Independent And Combined Effects". XI. International Conference On Personel Relationships Poster, Halifax, Canada.

KOÇAK, E. (2008) Ergenlerde Yalnızlığın Yordayıcısı Olarak Benlik Saygısı Ve Sürekli Öfke Ve Öfke İfade Tarzlarının İncelenmesi, T.C, Çukurova Üniversitesi, Sosyal Bilimler Enstitüsü, Eğitim bilimleri Anabilimdalı, Yüksek Lisans Tezi, Adana.

MALKOÇ, A.(2011) Öznel İyi Oluş Müdahale Programının Üniversite Öğrencilerinin Öznel İyi Oluş Düzeylerine Etkisi. T.C., Marmara Üniversitesi, Eğitim Bilimleri Enstitüsü, Eğitim Bilimleri Ana Bilim Dalı, Psikolojik Danışma Ve Rehberlik Bilim Dalı, Doktora Tezi, İstanbul.

MELLOR D., STOKES M., FIRTH L., HAYASHI Y., CUMMINS R. (2008) "Need For Belonging, Relationship Satisfaction, Loneliness And Life Satisfaction". Personality and Individual Differences $45,213-218$.

MERCAN, N., OYUR E., ALAMUR B., GÜL S., BENGÜL S. (2012) "İşyeri Yalnızlığı Ve Sosyal Fobi Arasındaki İlişkiye Yönelik Bir Araştırma”. Organizasyon Ve Yönetim Bilimleri Dergisi, Cilt 4, Sayı 1.

MERCAN N., DEMIRCI K., ÖZLER D. E., OYUR E. (2013) "İş Yaşamında Yalnızlık, Duygusal Zeka Ve Psikolojik Sermaye Arasındaki İlişkiler Üzerine Bir Araştırma”. Sakarya Üniversitesi,1. Örgütsel Davranıs Kongresi Bildiriler Kitabl.

OKTAN, V.(2012) "Beden İmajı Ve Reddedilme Duyarlılığının Öznel İyi Oluşu Yordama Gücü”. Eğitim Bilimleri ve Uygulama, 11 (22), 119-134.

PEPLAU, L.A., PERLMAN, D. (1982) Perspectives on loneliness. In: Peplau, L.A., and Perlman, D., eds. Loneliness: A Sourcebook of Current theory, research and therapy. New York: Wiley-Interscience.

PERLMAN, D., PEPLAU, L. A. (1981) Toward a Social Psychology of Loneliness, R. Gihour (Eds. ), Personal Relationships in Disorder. London: Academic Press, Predictors Of Happiness And Loneliness, Journal of Adolescence 25, 327-339.

REHDANZ, K., MADDISON, D.(2005) "Climate and Happiness". Ecological Economics 52, 111- 125.

Şİ̧̧MAN, M. TURAN, S.(2004) "Bazı Örgütsel Değişkenler Açısından Çalışanların İş Doyumu Ve Sosyal Duygusal Yalnızlık Düzeyleri (MEB Şube Müdür Adayları Üzerinde Bir Araştırma)”. Osmangazi Üniversitesi, Sosyal Bilimler Dergisi, Cilt: 5 Sayl: 1 Haziran. 
UZUNER, M. E. KARAGÜN, E. (2014) "Rekreatif Amaçlı Spor Yapan Bireylerin Yalnızlık Düzeylerinin İncelenmesi”, Kocaeli Üniversitesi Sosyal Bilimler Dergisi, , 27, 107-120.

WRİGHT S.L., BURT C.D.B., STRONGMAN K.T.(2006) Loneliness İn The Workplace: Construct Definition And Scale Development, New Zealand Journal of Psychology, V:35, N:2,July,s:59-68.

YAŞAR, M. R. (2007) "Yalnızlık". Fırat Üniversitesi, Sosyal Bilimler Dergisi, Cilt:17, Say1:1, 237-260, Elazı̆.

YILMAZ E., ASLAN H. (2013) “Öğretmenlerin İş Yerindeki Yalnızlıkları Ve Yaşam Doyumları Arasındaki İlişkinin İncelenmesi”. Pegem Eğitim ve Öğretim Dergisi, 3(3),s:59-69.

YURCU, G. (2014) Konaklama İşletmelerinde Çalışanların Örgütsel Vatandaşlık Davranışlarının İş Doyumu Ve Öznel İyi Oluşlarına Etkisi, T.C., Adnan Menderes Üniversitesi, Sosyal Bilimler Enstitüsü, Turizm İşletmeciliği Anabilim Dalı, Yayınlanmamış Doktora Tezi, Aydın.

YÜKSEL, M. Y., ÖZCAN Z., KAHRAMAN, A. (2013) "Orta Yaş Öğretmenlerin Yalnızlık Düzeylerinin Bazı Değişkenler Açısından İncelenmesi”. Eğitim ve Öğretim Araştırmaları Dergisi, Kasım, Cilt:2 Say1:4. 